\title{
DIGITAL LITERACY AND PRIMARY EDUCATIONAL SYSTEM IN NIGERIA
} https://doi.org/10.47743/jopafl-2021-20-13

\author{
Germaine O. J. IMHANYEHOR \\ First City Monument Bank, Benin City, \\ Edo State, Nigeria \\ gerimhans@yahoo.com
}

\begin{abstract}
Despite the enormous potential of ICTs and digital literacy in the educational setup, most primary schools in Benin City are yet to fully implement and take advantage of its numerous benefits to the teaching and learning process. This study therefore examined the possibility of incorporating digital literacy at the primary school level as well as ascertains the extent to which electronic gadgets are available and accessible and the challenges militating against the implementation of digital literacy in private primary schools in Benin City. The research design adopted for this study is descriptive survey. Using the stratified random sampling technique, a total of 448 primary school teachers responded to the Digital Literacy Questionnaire in Primary School (DLPQS) that was developed by the researcher and used for data collection. The data analysis was done using simple tables of frequency counts and percentages. Findings from the study revealed that whilst $90.2 \%$ of the teachers possessed Personal Computers (PC) and other electronic gadgets and were relatively proficient with the use of said devices, computers and digital gadgets were not readily available and accessible as $52.7 \%$ of the teachers taught in schools that did not currently have a computer lab with $60.7 \%$ not having access to the lab. Where available, $69.4 \%$ of the teachers indicated that most of the computers where outdated and not functional and $79.5 \%$ reported that the number of computers were insufficient. Findings also showed that - lack of / insufficient number of computers, poor internet connectivity and epileptic power supply were the major drawbacks in the use of digital literacy in the primary schools.
\end{abstract}

Keywords: Digital Literacy, Primary Schools, Educational System, Information and Communication Technology

\section{Introduction}

The concept of digital literacy as a subject matter is very broad with a variety of definitions and a range of applications to virtually all walks of life. With regards to the educational system in general and primary school education in particular, digital literacy can be defined as the capacity of an individual to know when and how to use digital technology to access, process, evaluate, create and communicate information through writing and other media on various digital platforms (Rubble and Bailey, 2007). It is one of the numerous benefits of the 21st century breakthrough in Information and Communication Technology (ICT) that has led to the increased use of technological devices like computers, mobile phones, televisions and DVDs as well as the internet to create, manage and distribute information. This breakthrough in information and communication technology in recent years has had significant impact on the different sectors of the economy including education. The advancement in technology has led to the era where learning through the internet is a possibility. With respect to education, increased access to the internet and improved availability of learning materials and technological gadgets has led to the breaking of the restriction to a particular place and time for both 
students and instructors before learning can occur that plagued the pre ICT era. This undeniable growth in the educational system due to the use of internet and the availability of digital outlets like audio and video CDs among others that has undoubtedly made the task of the teachers and students easier have mostly been implemented at the secondary and tertiary institutions with varying degrees of success dependent on peculiarities and challenges inherent at the geographical locations at which it has been implemented.

For countries in Europe and America, digital literacy is an integral part of their educational system with well structured digital innovations that have led to relative success in the use of internet and other digital literacy components. It has been of enormous benefits to their students in various learning institutions at different levels relative to Sub Saharan Africa in general and Nigeria in particular. For us here in Nigeria, our educational system is divided into primary (6 years), secondary (6 years) and tertiary (4 years) levels with the primary level of education designed as the foundation upon which higher levels of education are built. Despite the willingness and pledged commitment by the Nigerian government and relevant stake holders in educational planning and management to inculcate computer appreciation in our educational systems, Nigeria is yet to fully incorporate digital literacy into its curriculum and subsequently implement it at all levels (Achuonye 2012; Damkor et al., 2015). Findings from previous studies have shown that effective computer literacy skills and subsequent utilizations in Nigeria has been significantly hindered by factors such as availability and accessibility of computers to classrooms, teacher quality and teaching method, learning environment and learner characteristics. Most of the studies conducted by indigenous researchers (list 6 journal authors) have focused majorly on the application of the various forms of computer literacy and e-learning to different secondary and mostly tertiary institution. There appear to be a neglect of studies on the incorporation and subsequent evaluation of digital literacy among primary schools in Nigeria. This study is therefore set to conduct an in-depth research into digital literacy in primary schools in Nigeria.

\section{Statement of the Problem}

The primary education system in Nigeria is designed such that it is the foundation on which other levels of education are built. To achieve its aim of equipping pupils for further studies and adequately grooming them to function effectively in a continuously growing and fast paced digital driven world, it is imperative that the relevant stake holders in education incorporate the basic elements of digital literacy in the primary school curriculum and that teachers implement them accordingly. However, the adoption and utilization of computers and electronic gadgets by teachers, school administrators and pupils for teaching and learning as well as administrative purposes require that (i) teachers are competent (ii) these electronic gadgets are available and accessible (ii) the conditions are suitable for its use. Despite the enormous potentials of ICTs and digital literacy in the educational setup, the reality however is that most educational institutions in Nigeria particularly at the primary level are yet to fully implement and take advantage of its numerous benefits to the acquisition, processing, storing and dissemination of audio, video, textual, pictorial and numerical information necessary in the teaching and learning process (Ogundele and Etejere, 2013; Damkor et al, 2015). This is perhaps due to the peculiarities of the Nigerian educational setup and other challenges yet to be identified. Given the seeming shortage of literature on the subject matter in Nigeria, this research is therefore 
saddled with the responsibility of examining the possibility of incorporating digital literacy at the primary school level, ascertaining the extent to which electronic gadgets are available and accessible as well as identify the challenges militating against the implementation of digital literacy in private primary schools in Benin City.

\section{Aim and Objectives of the Study}

This study seeks to examine the possibility of incorporating digital literacy at the primary school level for pupils attending private schools in Benin City, Edo state, Nigeria. The specific objectives of this study are to:

Evaluate the progress made with respect to the implementation of digital literacy in private primary schools in Benin City, Edo state, Nigeria.

Identify and investigate the challenges of implementing digital literacy in private primary schools in Benin City.

Provide useful insight necessary for the incorporation of digital literacy in private primary schools.

\section{Significance of the Study}

Given the fact that most studies on digital and computer literacy in Nigeria have focused on secondary and tertiary levels of education creating a significant gap in the literature of digital literacy at the primary educational level, it is our hope that this study will help fill that gap in Benin City by simultaneously providing useful insights necessary for the implementation of digital literacy at the primary school level in Benin City and acting as a wakeup call to both the teaching staff at the various primary schools in Benin City who are not currently proficient in the use of digital technologies for the delivery of their lessons and the relevant government authorities to step up efforts to increase availability and accessibility of computers and digital technology gadgets. It would also contribute significantly to the body of existing knowledge on digital literacy in Nigeria thereby providing academic researchers in the field of digital and information literacy skills the necessary background information relevant for their research. Primary school administrators could also find it useful in the planning, budgeting and provision of digital facilities and electronic gadgets.

\section{Literature Review}

\section{The concept of digital literacy}

The term “digital literacy” which was first introduced and defined by Gilster (1997) as "the ability to understand and use information in multiple formats from a wide range of sources when it is presented via computers" has since become an all-encompassing phrase that has enjoyed a range of uses in the ICT literature (Eshet-Alkalai, 2004). While Bruce and Peyton, (1999) and later Davies et. al., (2002) used the term "digital literacy" to describe the technical and operational skills required for optimal computer usage, other researchers further extended the definition to both include information literacy and highlight the higher-order cognitive aptitude required to access, analyze, and create information via the utilization of digital resources and technological gadgets (Tapscott, 1998; Van Laar et. al., 2017). Other researchers who have attempted to define the concept of digital literacy includes: Eshet-Alkalai, (2002); Eshet-Alkalai and Amichai-Hamburger, 
(2004); Aviram and Eshet-Alkalai, (2006); Jones Kavalier and Flannigan, 2008). Beyond the ability to use software and operate digital devices properly, Eshet-Alkalai, (2002) defined Digital Literacy as a large varietyof complex cognitive, motor, sociological, and emotionalskills, which users need to function effectively indigital environments. Further research by Eshet-Alkali \& Amichai-Hamburger, (2004) revealed that the concept of Digital Literacy which has become a basic and necessary survival skill in the technological era "comprises of a growing variety of cognitive skills that are extensively utilized while working intuitively in the execution of both simple and complex task in digital environments". Digital literacy is therefore a combination of skills - technical, procedural, cognitive and social-emotional (Aviram \& Eshet Alkali, 2006). As the interconnection of digital technologies and literacy becomes more elaborate, the need for the introduction of digital literacy into classroom activities for innovative classroom instructional practices significantly increases (Pacino and Noftle, 2011).

\section{Components of Digital Literacy}

Digital Literacy is a term that comprises of other elements of information and communication technology. To fully grab the concept of digital literacy and adequately define it, a look at the various components of digital literacy is both necessary and essential. According to Payton and Hague, (2010); creativity, critical thinking and evaluation, cultural and social understanding, collaboration, ability to find and select information, effective communication, e-safety and functional skills are the eight components of digital literacy. Belshaw, (2011) opined that there are eight essential elements of digital literacy and that anyone seeking to fully harness their digital literacy skills ought to develop skills, attitudes and aptitudes in the eight areas which he identified as: cultural, cognitive, constructive, communicative, confidence, creative, critical and civic. Applying these essential elements to a particular context is essential to adequately defining "digital literacy". Greene and Copeland, (2014) argues that the two critical aspects of Digital Literacy as it relates to the growing prominence of the internet as educational tools are: (1) the ability to effectively plan and monitor the efficacy of strategies used to search and manage wealth of information available online and (2) the knowledge to appropriately vet and integrate those information sources. Garcia and Weiss, (2017) referred to the components of digit literacy as a set of digital skills, knowledge and understanding that are required for digital participation and necessary to survive and be productive in the digital era. He opined that Photo-Visual literacy, Information literacy, Social-economic literacy, Reproduction literacy and branching literacy are the five basic components of digital literacy for which a potential digital literate should possess the requisite skills needed to be a relevant and informed digital participant. For effective preparation and subsequent delivery of lessons to pupils in primary school, there is need for primary school teachers to develop these basic components of digital literacy skills.

\section{Digital Literacy and Primary School Education in Nigeria}

The world has continued to advance at a rapid rate and events have continued to move to the electronic stage with technology permanently altering the way pupils and students learn. The recent outbreak of the novel coronal virus pandemic has further strengthened the case for the inclusion of virtual and e-learning which requires teachers and pupils to be digital literates. Beyond the basic ability to read, write, calculate, 
communicate and comprehend, the demands of today's world require students who can embrace information technologies, artificial intelligence and their application (Breen, 2017). With regards to primary school education in Nigeria, a significant number of school children and their teachers still lack access to digital technologies and the requisite technical know-how to utilize them despite the fact that majority of the pupils were born into the internet enabled "always-connected life" (Kavanagh and O'Rourke, 2016) and at a time when computers and devices have become relatively cheaper and easier to use (Belshaw, 2011).

Due to poor funding of government owned primary schools and the resultant dilapidated buildings housing crowded classrooms, most Nigerian children attending those schools can only think of the nonexistent computers and other digital gadgets as luxuries. Where available, the ratio is always ridiculously unbalanced. For those whose parents can afford to pay the exorbitantly high tuition fees for decent private primary and secondary schools, the use of digital gadgets, computers and the internet is already an integral part of their daily life. Unfortunately, they are not familiar with or use technology for learning purposes (Waycott et. al., 2010). The majority of them employ the use of their mobile devices, computers and tablets for social and entertainment purposes rather than learning (Prior et al., 2016). As a result, studies by Gurung and Rutledge, (2014) are of the opinion that pupils in primary schools who are already exposed to the internet and other digitally enabled platforms (digital learners) need help to apply technology effectively for learning to prepare them for further education and help them develop skills for living, learning and working in a digital society now leaning towards artificial intelligence. Unfortunately, most of the primary school teachers who are supposed to teach and offer guidance do not possess those capabilities. If we are to achieve the UN's Sustainable Development Goal 4 target of equipping young people and adult with the relevant skills for decent employment and entrepreneurship by 2030 and prepare the next generation for the challenges of surviving in a continuously evolving digital age now leaning towards automation and artificial intelligence, then there is need for teachers to be made aware of how digital tools can be best used to enhance pupils and student's learning and engagement in the classroom.

\section{Challenges in Digital Literacy Application in Nigerian Primary Educational System}

Whilst the application and use of ICT and digital literacy by most European countries has led to transformational changes in their educational landscape at both the primary, secondary and tertiary levels particularly through the instructional process (Kosakowski, 1998) its impact in the Nigerian educational setup at all levels has been relatively minimal due to peculiar challenges that has plagued its integration and implementation process for years. Most primary and secondary educational institutions both private and government owned still carry out their teaching and learning process using chalk boards in physical classrooms devoid of computers or any other digital gadgets/equipments required for the preparation and delivery of digitally inclusive teaching and learning process (Achuoye, 2012). According to Aduwa-Ogiegbaen and Iyamu (2008), factors such as - high cost of computers, weak infrastructures resulting to both epileptic power supply and inadequate telecommunication facilities, lack of the requisite skills by teachers to fully utilize technology in curriculum implementation, lack of relevant soft ware's for content creation and effective teacher-student communication that is culturally suitable to the Nigerian educational system and limited access to the internet were 
identified as some of the factors militating against the effective utilization of computers in Nigerian primary and secondary schools. This is in line with the thoughts of Damkor et al. (2015), who opined that other than poor computer literacy skills of secondary school teachers, efforts geared towards the integration and subsequent utilization of digital literacy for teaching purposes have not had much impact due to challenges such as lack of computers due to high cost and poor maintenance, lack of electricity and slow internet connectivity as well as increased moral degradation due to pornography and cyber bullying. Bada et al. (2009) noted that the challenges of computer and digital literacy in Nigerian primary and secondary schools are both educational and administrative. Prominent among the administrative problem is the high cost of installation, maintenance and replacement of computers, projectors and other digital gadgets, meager funding of education due to the depressed economic situation of Nigeria, resistance to change syndrome and dearth of instructional facilities.

\section{Appraisal of Literature}

The foregone discussion on the available relevant literatures relating to digital literacy as reviewed by the researcher revealed that although a lot of researches have been carried out on digital literacy in past and recent times, not many and specific studies have been conducted in relation to digital literacy and primary educational system in Benin City. Most of the researches carried out were based on foreign institutions with the few indigenous researchers focusing on digital literacy at the secondary and tertiary levels of education. It is against this background, and scarcity of research work on digital literacy at private primary school level that this study is set to evaluate the progress made with respect to the implementation of digital literacy in private primary schools in Benin City as well as identify and investigate the challenges of implementing digital literacy in private primary schools.

\section{Research Methodology}

\section{Research Design}

The research design adopted for this study is survey. A survey research method is a type of research in which information is obtained from a sample of respondents for the purpose of testing hypothesis or answering research questions concerning the states of a given problem (Sambo, 2005). Therefore, the use of survey research method will allow the researcher to measure the opinion, behavior, and experience of the private primary school teachers in Benin City (Population of the study) by studying a small sample from that group (teachers from the randomly selected schools in each LGA) given that it is impossible or impracticable to observe all members of the population; then generalizing back to the population. This therefore means that the method is efficient in getting information on the opinions, feelings and attitudes of the respondents, in this case, towards the availability, accessibility and use of digital literacy gadgets in private primary schools.

\section{Population of the Study}

The focus of this research is on digital literacy skills and implementation levels in the Nigerian educational system at the elementary school stage. The study covers all the private schools in the five local government areas in Benin City. The population - defined 
as "the collection of individuals with similar characteristics where the sample is picked from in the belief that generalization can be made" (Babbie, 2010) of the study consist of the teachers and administrative staffs of all private primary schools in Benin City, the capital of Edo State, Nigeria. The research was conducted in Benin City, the capital of Edo State, Nigeria. There are five local governments in the city. Private primary schools will be chosen from each of the five Local Government Areas and used for the study.

\section{Sample and Sampling Technique}

The sampling procedure used in this study is the stratified random sampling. The decision to employ the stratified random sampling technique for this research was based on the need to give each private primary school teacher in Benin City an equal chance of being selected irrespective of the local government in which the school they teach is situated within the state. First, the private primary schools in Benin City were divided into five (5) strata corresponding to the five Local Government Areas in Benin City. The five local government areas which were used to represent each stratum are: Oredo, Egor, Ikpoba-Okha, Ovia-North-East and Uhunmwonde. From each of the five strata, ten (10) private schools were selected at random. This brought the total number of schools that was selected for the sampling exercise to fifty (50). Next, ten (10) teachers / management staff was selected from each school based on subject areas using simple random sampling method. This implies that for each strata, 100 staffs (10 teachers per school $\times 10$ schools) were selected leading to an overall sample size of 500 teachers / management staff who were administered the research instrument.

\section{Instrument for Data Collection}

The instrument for data collection is the researcher's self developed questionnaire tagged Digital Literacy Questionnaire in Primary Schools DLQPS (see Appendix). The use of the questionnaire was subject to approval from my academic supervisor after validation. The research instrument is made up of four parts. The first part is concerned with the demographic characteristics of the respondents. The focus of the second part is on the availability of ICT facilities for use among private primary schools in Benin City. Part 3 consists of 24 items bothering on the ICT proficiency levels among private primary school teachers. Part 4 samples questions targeted at revealing the challenges to digital literacy implementation. Part 4 also contain items addressing key questions necessary for actualizing the aims and objectives of the research. The questionnaire is on a four point scale in which primary school teachers are expected to tick their responses to the under listed statement in each part. In response to the items in the research instrument (questionnaire) to be administered to the participants of this study, the following keys were used: Key: Yes (Y); No (N); Strongly Agree (SA); Agree (A); Disagree (D); Strongly Disagree (SD); Beginner (B); Intermediate (I); Advance (AD); Expert (E); True (T); False (F).

\section{Validity and Reliability of Research Instrument}

Validity is the measurement of how well a research instrument examines what it is supposed to examine. It is the extent to which a concept, conclusion or measurement is well founded, accurately reflecting the meaning of the concepts under study (Osuala, 2005; Babbie, 2010). In line with standard research practice, validation of the research instrument 
to ensure that the DLQPS is well founded and adequately measures the various components of digital literacy among private primary school teachers in Benin City, the researcher has therefore (i) made the questions in the instrument relevant, clear and unambiguous (ii) ensured that the questions cover as much as possible, all the dimensions of digital literacy variables (iii) submitted the questionnaire to my academic supervisor for critical evaluation and scrutiny of content relevance, coverage and clarity (iv) make necessary amendments based on the suggestions from my supervisor. Furthermore, the Cronbach's alpha coefficient was employed to ascertain and ensure the reliability of the research instrument. A reliable study produces a consistent, precise, and accurate variable that does not fluctuate over time when repeatedly measured (Ojebode et al., 2010). A research instrument with a Cronbach's value of 0.7 or above is reliable (Ary et. al., 2006).

\section{Method of Data Collection}

To obtain the data for use in this study, the researcher personally administered the questionnaire to the teachers in each of the selected schools to ensure that the target population received and filled the questionnaire. This was done to increase the response rate and ensure an increased level of accuracy. Due to the geographical distance between the primary schools in each of the different local government, the time for administering and retrieval of the research instrument was ten working days. This implied that the researcher spent two (2) working days in each of the five (5) Local Government Areas where the randomly selected schools were located.

\section{Method of Data Presentation and Analysis}

To carry out the data analysis, information obtained from the research instrument that was administered to and retrieved from the respondents will be interpreted in order for the information to be readable, accessible and understandable. This process will involve tabulating, editing, and coding the data in order to determine the extent to which digital literacy gadgets are available and accessible in primary schools as well as the digital literacy proficiency level of primary school teachers and their level of application of computer and digital equipments to the preparation and delivery of their lessons. Quantitative data collected from respondents through questionnaire will be analyzed using descriptive statistics (frequency counts, percentages, mean and maybe standard deviation) and presented in simple tables and charts based on the objectives of the study.

\section{Data Presentation, Analysis and Interpretation}

The presentation and analysis of data is done in stages under carefully crafted subheadings for the actualization of the study objectives. The first section of this chapter is a review of the demographic characteristics of the respondents. This is followed by an examination of the data with a view to finding answers to the three research questions that this study seeks to answer. Thereafter, a recap of the study's key results and findings is presented. Five hundred (500) copies of the questionnaire were administered and four hundred and forty-eight (448) were retrieved. This resulted in a response rate of $89.6 \%$. 
Demographic Characteristics of Respondents

Tables $1-4$ below are a summary of the demographic characteristics of the participants based on gender, age, teaching experience and academic qualifications.

Table 1: Distribution of Respondents by Gender

\begin{tabular}{|c|c|c|}
\hline Gender & Frequency & Percentage \\
\hline Male & 198 & 44.2 \\
\hline Female & 250 & 55.8 \\
\hline Total & 448 & 100 \\
\hline
\end{tabular}

Source: Researcher's survey, 2021

The statistics from Table 1 shows that 198 respondents from the selected private primary schools which represent $44.2 \%$ are males while 250 of the respondents which represent $55.8 \%$ of the study participants were female teachers.

Table 2: Distribution of Respondents by Age Range

\begin{tabular}{|c|c|c|}
\hline Age Range (years) & Frequency & Percentage \\
\hline Below 30 & 238 & 53.1 \\
\hline $30-50$ & 194 & 43.3 \\
\hline Above 50 & 16 & 3.6 \\
\hline Total & 448 & 100 \\
\hline
\end{tabular}

Source: Researcher's survey, 2021

With $53.1 \%$ of the respondents below the age 30, Table 2 clearly shows that a greater percentage of the respondents were young adults with respondents between the age brackets of $(30-50)$ years accounting for $43.3 \%$. Only sixteen respondents (3.6\%) were above the age of 50 years.

Table 3: Distribution of Respondents by Teaching Experience

\begin{tabular}{|c|c|c|}
\hline Teaching Experience (years) & Frequency & Percentage \\
\hline $1-3$ & 214 & 47.8 \\
\hline $4-10$ & 180 & 40.2 \\
\hline Above 10 & 54 & 12.0 \\
\hline Total & 448 & 100 \\
\hline
\end{tabular}

Source: Researcher's survey, 2021

Table 3 reveals that a larger percentage of the respondents (47.8\%) had less than five years teaching experience. This is hardly surprising giving that over fifty percent of them were less than 30 years of age. Only 54 of the respondents (12\%) had more than 10 years teaching experience.

Table 4: Distribution of Respondents based on Academic Qualification

\begin{tabular}{|c|c|c|}
\hline Academic Qualification & Frequency & Percentage \\
\hline NCE & 160 & 35.7 \\
\hline B.Sc. / B.Ed. & 192 & 42.9 \\
\hline M.Sc. / M.Ed. & 28 & 6.3 \\
\hline Others & 68 & 15.1 \\
\hline
\end{tabular}




\begin{tabular}{|c|c|c|}
\hline Total & 448 & 100 \\
\hline Source: Researcher's survey, 2021 &
\end{tabular}

Table 4 above shows that 160 study participants (35.7\%) held a National Certificate in Education NCE while $42.9 \%$ of the respondents were Bachelor's degree holders with only 28 teachers $(6.3 \%)$ possessing a master’s degree.

\section{Assessment of the Availability of Digital Gadgets}

Table 5 displays the level of availability and accessibility of technological devices such as computers, handheld devices, television, DVD's and digital cameras in response to the first research question "To what extent are technological devices and electronic gadgets available and accessible for classroom instructors in private primary schools in Benin City?” using information obtained from section A of the research instrument.

Table 5: Availability and Accessibility of Digital Gadgets

\begin{tabular}{|c|c|c|c|c|c|}
\hline $\mathrm{S} / \mathrm{N}$ & ITEMS & \multicolumn{2}{|c|}{ YES } & \multicolumn{2}{|c|}{ NO } \\
\hline & Availability of Digital Gadgets & Freq. & $\%$ & Freq. & $\%$ \\
\hline 1 & Do you have a personal computer or handheld device? & 404 & 90.2 & 44 & 9.8 \\
\hline 2 & Does your school have a computer lab? & 212 & 47.3 & 236 & 52.7 \\
\hline 3 & Do you have access to the computer room? & 176 & 39.3 & 272 & 60.7 \\
\hline 4 & $\begin{array}{c}\text { Do you have any official electronic device given to you for the } \\
\text { preparation and delivery of your lesson plans? }\end{array}$ & 124 & 27.7 & 324 & 72.3 \\
\hline 5 & Does your school have a website or e-learning platform? & 208 & 46.4 & 240 & 53.6 \\
\hline 6 & $\begin{array}{l}\text { Does your school have Wi-Fi or any other form of internet } \\
\text { connectivity? }\end{array}$ & 152 & 33.9 & 296 & 66.1 \\
\hline
\end{tabular}

Source: Researcher's survey, 2021

With regards to the research question on the availability and accessibility of computers and other digital gadgets, Table 5 shows that although $90.2 \%$ of the respondents possessed Personal Computers (PC) and other handheld devices, only 212 respondents (47.3) indicated that there was a computer lab in the school where they taught. Where available, only $39.3 \%$ of the respondents had access to the computer labs with over $60 \%$ not having access to the computer room. This indicates that to a large extent, computers and digital gadgets are not readily available and accessible in the private primary schools in Benin City. This narrative is further strengthened by the fact that only $27.7 \%$ of the respondents were officially given computers and other electronic gadgets for the teaching and preparation of their lesson plans. The table also revealed that there was little to no WiFi or internet connectivity with only 152 respondents (33.9\%) admitting that there was internet connectivity within the school premises with over $66 \%$ not having Wi-Fi or internet connection.

\section{Assessment of Teacher's Digital Literacy Proficiency}

Tables 6 displays the level of proficiency of the study participants in response to the second research question "Are the private school teachers and instructors proficient in 
the use of computers and the internet?” using information obtained from section B of the research instrument.

Table 6: Distribution of Teacher's Proficiency Level

\begin{tabular}{|c|c|c|c|c|c|}
\hline $\mathrm{S} / \mathrm{N}$ & ITEMS & \multicolumn{2}{|c|}{ YES } & \multicolumn{2}{|c|}{ NO } \\
\hline & Digital Literacy Proficiency & Freq. & $\%$ & Freq. & $\%$ \\
\hline 1 & Can you turn on and shut down a computer correctly? & 386 & 86.2 & 62 & 13.8 \\
\hline 2 & Do you know how to install a software programme? & 285 & 63.6 & 163 & 36.4 \\
\hline 3 & Can you create and edit a basic Word document? & 296 & 66.1 & 152 & 33.9 \\
\hline 4 & Can you create and edit a basic Excel spreadsheet? & 281 & 62.7 & 167 & 37.3 \\
\hline 5 & $\begin{array}{c}\text { Can you create a simple presentation using Power } \\
\text { point? }\end{array}$ & 278 & 62.1 & 170 & 37.9 \\
\hline 6 & Can you write files onto a CD, DVD or USB drive? & 240 & 53.6 & 208 & 46.4 \\
\hline 7 & $\begin{array}{c}\text { Can you download and use educational apps on digital } \\
\text { devices? }\end{array}$ & 264 & 58.9 & 184 & 41.1 \\
\hline 8 & $\begin{array}{l}\text { Can you search for information online using web } \\
\text { search engines? }\end{array}$ & 356 & 79.5 & 92 & 20.5 \\
\hline
\end{tabular}

Source: Researcher's survey, 2021

From the table, 386 respondents (86.2\%) could boot and shut down a computer correctly while $63.6 \%$ of them could install soft ware programs on the computer by themselves. This is hardly a surprise given that (from Table 5), over $90 \%$ of the respondents owned a Personal Computer (PC). Furthermore, results obtained from the responses of the study participants showed that over $60 \%$ of respondents were comfortable using Microsoft Office programs for either creating a basic word document, spreadsheet or for making simple presentations using power point. This indicates that most of the primary school teachers were relatively proficient in the use of computers. With 264 respondents (58.9\%) being able to download and use educational app on digital devices, we can infer that the teacher are also comfortable surfing the internet. This deduction is further strengthened by the fact that 356 respondents (approximately 80\%) could search for information online using web search engines.

\section{Assessment of the Challenges of Digital Literacy Implementation}

Tables 7 is a display of the challenges of digital literacy implementation in response to the third research question "What are the challenges mitigating against the implementation of digital literacy in private primary schools in Benin City?” using information obtained from section $\mathrm{C}$ of the research instrument. From Table 7 above, a combined $79.5 \%$ of the respondents agree/admit that not having enough computers in the respective schools were they taught was a challenge with only about $21 \%$ disagreeing. With regards to electricity supply, a combined $88.8 \%$ of the respondents agreed that epileptic power supply/incessant power outage was a major setback to digital literacy implementation. The lack of Wi-Fi or internet connectivity within school premises had a combined $69.4 \%$ of the respondent in agreement with only $30.6 \%$ in disagreement. Although only $47.3 \%$ (from Table 5) of respondents taught in schools that had computer 
lab, yet a combined $69.4 \%$ admitted that the school computers are not functional or outdated. On the lack of the requisite computer and digital literacy skills of teachers, only $40 \%$ were in agreement with about $60 \%$ disagreeing. This is in line with deduction from Table 6 in section 4.4 where it was observed that most of the primary school teachers were relatively proficient. With only $32.6 \%$ of the respondents agreeing that most teachers were reluctant to use ICT at school, we can conveniently discard it as major hindrance to the implementation of digital literacy given that about $67 \%$ of the respondents disagreed.

\section{Summary, Conclusion and Recommendation}

\section{Summary of findings}

Findings from this study showed that although most of the primary school teachers owned personal computers (pc) and other handheld devices, and were relatively proficient, computers and digital gadgets are not readily available and accessible in the private primary schools in Benin City. The major hindrances to the implementation of digital literacy in the primary schools were lack of computers and internet connectivity along with epileptic power supply. Listed below are the findings from the field work carried out by the researcher. Most of the private primary school teachers possessed Personal Computers (PC) and/or other electronic gadgets and were also relatively proficient with the use of the said PC's and handheld devices as well as been able to surf the net in search of relevant information for use in their teaching. In the private primary schools were majority of the respondents taught in, computers and digital gadgets were not readily available and accessible as many schools do not currently have a computer lab. Where available, most of the computers were not functional, outdated or insufficient with little to no Wi-Fi and internet connectivity in most of the primary schools. Lack of / insufficient number of computers and internet connectivity along with poor power supply and incessant power outage were a major drawback in the implementation of the digital literacy in the primary schools.

\section{Conclusion and Recommendations}

In this study, an attempt has been made to examine the progress made with respect to the implementation of digital literacy in private primary schools in Benin City, Edo state, Nigeria as well as identify and investigate the challenges of implementing digital literacy in private primary schools in Benin City in the hope that the findings would provide useful insight necessary for the incorporation of digital literacy in private primary schools within the state. Whilst it is encouraging to note that most of the primary school teachers who are tasked with the responsibility of inculcating digital knowledge and awareness into the primary school pupils are relatively proficient in the use of computers and digital gadgets, findings from the study that revealed a relative lack of computers and digital gadgets in the selected primary schools within the state is disturbing given the fact that the world today is continuously leaning towards not just a digitally driven economy but one laced with Artificial Intelligence. The need to implement digital literacy into primary schools and equip the future leaders of this state with the requisite digital knowledge necessary to survive in the 21st century cannot be overemphasized. However, to expose pupils early to computer and digital literacy and prepare them adequately for both further studies and future work life, the challenges revealed by this study must first be navigated. The 
researcher has therefore made some recommendations based on the findings from this study. Arising from this study, the following recommendations are suggested:

To be more responsive to the needs of the society in line with the demands of the digital age, the researcher recommends that - the responsibility of integrating digital literacy into both private and government owned primary schools in Benin City and Nigeria at large be a shared collective effort from all stake holders ranging from the government through her various representative agencies to school administrators, teaching staff, parents and the pupils who are being taught. The State and Federal Government should ensure that it follows up on her past commendable efforts such as the establishment of the Digital Literacy Council of Nigeria in 2017 and the partnership entered into by "The National Information Technology Development Agency (NITDA)" with the Nigerian Union of Journalist (NUJ), FCT council on digital literacy and skill acquisition in Nigeria through prompt interventions in the areas of ICT deployments by tackling the challenges of digital literacy highlighted in this study via the provision of adequate funding, electricity and internet connectivity as well as subsidizing the cost of computer installations/maintenance.

School Administrators and Primary School Management Board should constantly organize extensive seminars, workshops and trainings on the use of digital technology in the classroom to regularly update teacher's digital literacy competency and keep them abreast with best practices in an ever evolving digital world as well as instill confidence in their ability to effectively incorporate digital technology into daily classroom usage. On the part of the parents, it is recommended that they constantly pay close attention to the online and offline activities of their children/ward that have access to mobile devices, personal computers and the internet.

\section{Contribution to Knowledge}

This study has contributed to existing knowledge by:

- filling the gap in the literature of digital literacy at the primary educational level in Benin City, Edo state, Nigeria occasioned by the focus of indigenous researchers on the application of the different forms of digital literacy and e-learning at the secondary and tertiary levels of education.

- providing useful insights necessary for the implementation of digital literacy at the primary school level in Benin City

\section{Strength and Limitation of the Study}

This study is one of the foremost in Nigeria to consider digital literacy and the primary educational system with a view to evaluating the progress made with respect to the implementation of digital literacy in private primary schools in Benin City, Edo state, Nigeria. On the strength of this study are the sample size and the relatively low non response rate, with over $89 \%$ of the study participants completing the survey instrument? Furthermore, respondents were made anonymous and their responses kept strictly confidential. However, this study has a few drawbacks in that this research did not consider teachers in public primary schools neither did it take a cursory look at the ratio of computers to pupils in the schools that had computer labs and the possibility of the use of the said computers in the preparation / delivery of lesson plans. Another possible limitation to this study is one that is common to all survey based research and that is conscious or subconscious opinion bias of the respondents. 


\section{Suggestion for Further Studies}

Based on the limitation and findings of this study, the following suggestions for future research are suggested. First of all, the present study was focused on only private primary schools in Benin City. Future research should therefore consider the survey of public primary schools teachers within the state. Although the findings obtained from the study could be relevant and useful in other parts of Nigeria, it is suggested that other researchers replicate the study in other defined geographical locations across the country.

\section{Implication of the Study for Practice or Policy}

After answering the research questions posed in this study, it is the hope of the researcher that the results obtained would (i) provide useful insights necessary for the implementation of digital literacy at the primary school level in Benin City (ii) act as a wakeup call to the few teaching staffs at the various primary schools in Benin City who are not currently proficient in the use of digital technologies for the delivery of their lessons (iii) make the relevant government authorities to step up efforts to increase availability and accessibility of computers and digital technology gadgets (iv) contribute significantly to the body of existing knowledge on digital literacy in Nigeria thereby providing academic researchers in the field of digital and information literacy skills the necessary background information relevant for their research.

\section{References}

1. Achuonye, K. A. (2012). A Comparative Study of Computer Literacy in Urban and Rural Primary Schools in Rivers State of Nigeria. Journal of Sociological Research, 3(2).563-578. http://dx.doi.org/10.5296/jsr.v3i2.2893

2. Aduwa-Ogiegbean, S. E., and Iyamu, E. O. S. (2008). Using Information and Communication Technology in Secondary Schools in Nigeria. Educational Technology \& Society 8 (1),104-112. https://www.jstor.org/stable/jeductechsoci.8.1.104

3. Ary, D., Jacobs, L. C., Razavieh, A., and Sorensen, C. (2006). Introduction to research in education. Belmont,: Thomson Wadsworth.

4. Aviram, R. and Eshet-Alkalai, Y. (2006). Towards a theory of digital literacy: three scenarios for the next steps. European Journal of Open Distance E-Learning. http://www.eurodl.org/materials/contrib/2006/Aharon_Aviram.htm

5. Babbie, E. (2010). The practice of social research (12th ed.). Belmont, CA: Wadsworth, Cengage Learning

6. Bada, T., Ajibade, A. \& Ojedokun, O. (2009). Uses of computer and its relevance to teaching and learning in Nigerian educational system. Educational Research and Review. 4(10), 443 - 447. https://doi.org/10.5897/ERR.9000399

7. Belshaw, D. (2011). What is 'Digital Literacy'? [online] Available at: neverendingthesis.com/dougbelshaw-edd-thesis-final.pdf (accessed 21 November 2020).

8. Bowling, A. (2002). Research Methods in Health. Investigating Health and Health Services. Buckingham, UK and Philadelphia, PA: Open University Press.

9. Breen, C. (2017). Embracing Literacy in a Digital Age. Global Business Coalition for Education retrieved from gbc-education.org (accessed 21 November 2020).

10. Bruce, B. C., and Peyton, J. K. (1999). Literacy development in network-based classrooms: Innovation and realizations. Retrieved from https://www.ideals.illinois.edu/bitstream/handle/2142/13367/99enfi.pdf? 
11. Damkor, M., Irinyang, D. J., and Haruna, M. (2015). The Role of Information Communication Technology in Nigeria Educational System. International Journal of Research in Humanities and Social Studies 2(2) pp64-68

12. Davies, J., Szabo, M., and Montgomerie, C., (2002). Assessing Information and communication technology literacy of education undergraduates: instrument development. In: Barker, P., Rebelsky, S. (eds.), Proceedingsof ED-MEDIA, 2001 World Conference on EducationalMultimedia, Hypermedia \& Telecommunications.

13. Eshet, Y. (2002). Digital literacy: a new terminology framework and its application to the design of meaningful technology-based learning environments. In: Barker, P., Rebelsky, S. (eds.), Educational Multimediaand Hypermedia Norfolk, VA: Association for the Advancement of Computing in Education, pp. 493-498.

14. Eshet-Alkali, Y. (2004). "Digital Literacy: A Conceptual Framework for Survival Skills in the Digital Era”, Journal of Educational Multimedia and Hypermedia, 13(1), pp. 93-106.

15. Eshet-Alkali, Y., and Amichai-Hamburger, Y. (2004). Experiments in digital literacy. CyberPsychology \& Behavior, 7(4), 421-429.

16. Garcia, E., and Weiss, E. (2017). Education Inequalities at the School Starting Gate: Gaps, trends and Strategies to Address them. Report, Economic Policy Institute. Available at: epi.org/132500.

17. Gilster, P. (1997). Digital literacy. New York: John Wiley and Sons.

18. Greene, J. A., Yu, S. B. and Copeland, D. Z. (2014). Measuring Critical Components of Digital Literacy and their Relationships with Learning, Computers \& Education, Vol. 76, pp. 55-69. https://doi.org/10.1016/j.compedu.2014.03.008

19. Gurung, B. and Rutledge, D. (2014). "Digital Learners and the Overlapping of their Personal and Educational Digital Engagement”, Computers \& Education, Vol. 77, pp. 91-100. https://doi.org/10.1016/j.compedu.2014.04.012

20. Ifueko Omoigui Okaru (2011). "Emerging Issues in Tax Administration: The Way Forward” Being a lecture delivered at the 4th National Conference of the Dept. of Finance, Faculty of Business Administration, University of Lagos on July 12th, 2011.

21. Jones-Kavalier, B., and Flannigan, S. L. (2008). Connecting the Digital Dots: Literacy of the 21st Century. Teacher Librarian, 35(3), 13-16.

22. Kavanagh, A. and O'Rourke, K. C. (2016). Digital Literacy: Why It Matters. Learning,Teaching\& Technology Centre. https://arrow.tudublin.ie/ltcart

23. Kosakowski, J. (1998). The Benefits of Information Technology. The Educational Resources Information Centre ERIC Digest. ED420302 1998-06-00

24. Ogundele, M. O and Etejere, P. A. O (2013). Computer Literacy and Secondary School Teachers Job Effectiveness in Kwara State. African Journal of Teacher Education. 3(1); 23-29 https://doi.org/10.21083/ajote.v3i1.1958

25. Ojebode, A., Onekutu, P., and Adegbola, T. (2010). Audience Research method for campus radio station. Senegal, Institute for media and society and Panos Institute West Africa

26. Osuala, E. C. (2005). Introduction to Research Methodology. 3rd edition. Onitsha: Africana-First Publishers

27. Pacino, M. A., and Noftle, J. T. (2011). New literacies for global, digital learners. International Journal of Learning, 18(1), 477-485.

28. Payton, S. and Hague, C. (2010). Digital Literacy in Practice: Case Studies of Primary and Secondary Classrooms. $\quad$ Futurelab. [online] Available at: www2.futurelab.org.uk/resources/documents/project_reports/digital_literacy_case_studies.pdf (accessed 21 November 2020).

29. Prior, D. D., Mazanov, J., Meacheam, D., Heaslip, G., and Hanson, J. (2016). “Attitude, Digital Literacy and Self Efficacy: Flow-On Effects for Online Learning Behavior", Internet and Higher Education, Vol. 29, pp. 91-97. https://doi.org/10.1016/j.iheduc.2016.01.001

30. Rubble, M and Bailey, G. (2007). Digital Citizenship in Schools. Eugene, OR: ISTE, p.21

31. Sambo, A. A. (2005). Research Method in Education. Ibadan: Stirling Horden Publishers. 
32. Tapscott, D. (1998). Growing up digital: the rise of the net generation. New York: McGrawHill.Norfolk, VA: Association for the Advancement of Computing in Education, pp. 377-383.

33. Van Laar, E., Van Deursen, A. J., Van Dijk, J. A., and De Haan, J. (2017). The relation between 21st-century skills and digital skills: A systematic literature review. Computers in Human Behavior, 72, 577588. https://doi.org/10.1016/j.chb.2017.03.010

34. Waycott, J., Bennett, S., Kennedy, G., Dalgarno, B., and Gray, K. (2010). ”Digital Divides? Student and Staff Perceptions of Information and Communication Technologies", Computers \& Education, Vol. 54, pp. 1202-1211. https://doi.org/10.1016/j.compedu.2009.11.006

This article is an open access article distributed under the terms and conditions of the Creative Commons Attribution - Non Commercial - No Derivatives 4.0 International License. 